\title{
Collaborative Governance Networks: A Case Study of Argentina's Forest Law
}

\author{
Carla Inguaggiato ${ }^{1, *(\mathbb{D}}$, Michele Graziano Ceddia ${ }^{1}$, Maurice Tschopp ${ }^{1}$ and Dimitris Christopoulos ${ }^{2,3}$ \\ 1 Centre for Development and Environment (CDE), University of Bern, 3012 Bern, Switzerland; \\ michele.ceddia@cde.unibe.ch (M.G.C.); maurice.tschopp@cde.unibe.ch (M.T.) \\ 2 Department of Sustainability, Governance, and Methods, MODUL University, 1190 Vienna, Austria; \\ Dimitris.Christopoulos@modul.ac.at \\ 3 Centre for Networks and Enterprise Excellence (CNEE), School of Social Sciences, Heriot-Watt University, \\ Edinburgh 0131, UK \\ * Correspondence: carla.inguaggiato@cde.unibe.ch; Tel.: +41-31-684-30-59
}

Citation: Inguaggiato, C.; Ceddia, M.G.; Tschopp, M.; Christopoulos, D. Collaborative Governance Networks: A Case Study of Argentina's Forest Law. Sustainability 2021, 13, 10000. https://doi.org/10.3390/ su131810000

Academic Editor: Ivo Machar

Received: 25 June 2021

Accepted: 16 August 2021

Published: 7 September 2021

Publisher's Note: MDPI stays neutral with regard to jurisdictional claims in published maps and institutional affiliations.

Copyright: (c) 2021 by the authors. Licensee MDPI, Basel, Switzerland. This article is an open access article distributed under the terms and conditions of the Creative Commons Attribution (CC BY) license (https:// creativecommons.org/licenses/by/ $4.0 /)$.

\begin{abstract}
Deforestation causes biodiversity loss and the eviction of small-scale ranchers and indigenous people. Accordingly, it is a global issue in environmental politics. This article analyzes a participatory governance system associated with the implementation of Argentina's forest law in a hotspot of deforestation: the province of Salta in the Gran Chaco ecoregion. Specifically, this article investigates policy actors' core beliefs, how they match with policy network clusters, and how this affects the implementation of the forest law. The study is based on a unique data set derived from extensive fieldwork and a network survey among all actors who participate in the policy forums. After defining three main core beliefs that describe policy actors' motivations, we systematically analyze all key actors' beliefs as well as their interactions in the various policy networks. This analysis shows that it is necessary to empirically identify coalitions based on both behavior and core beliefs to understand the limited implementation of the law. Our methodological approach holds promise for the analysis of other governance systems where multiple stakeholders engage in consensus-oriented decision-making.
\end{abstract}

Keywords: collaborative governance; policy networks; Chaco Salteño; Argentina; forest law

\section{Introduction}

Deforestation, which causes biodiversity loss and the eviction of small-scale ranchers and indigenous people, is a global issue in environmental politics. This article analyzes the governance system associated with the implementation of Argentina's forest law in an area that constitutes a hotspot of deforestation: the province of Salta, in the Gran Chaco ecoregion [1].

In 2007, Argentina's adoption of the Federal Forest Law 26.331 (hereafter "forest law") marked a key change in government policy, making forest management a crucial issue in the national policy arena. The forest law represented a response to very high deforestation rates, especially in the northwest of the country [2].

Forest policy in Argentina builds on the concept of collaborative governance. The forest law prescribes that individual provinces must define their own implementation regulations to enforce the law through a participatory process (Art. 6, Law 26.331/2007). These policy forums (also referred to as multi-stakeholder platforms) are designed to serve as arenas in which actors with contrasting visions can meet and negotiate common solutions [3].

Implementation of the forest law has been described as weak by many observers, particularly in the province of Salta, where this is evidenced by continuing deforestation [4-6]. However, few studies have examined in detail the contrasting beliefs of all policy actors and how these beliefs take shape in coalitions through actors' interaction in policy networks. By 
doing so, this study complements previous literature [7] examining the behavior of coalitions in Salta. The present study does not take these coalitions for granted. Rather, focusing on one specific province, it provides a fine-grained analysis of the coalitions' structure and functioning. The way in which actors coordinate their activities has an impact on the strength of their coalitions. This article provides some evidence regarding sources of the weakness of conservation coalitions in Salta mentioned in previous studies [8].

The present study relies on the advocacy coalition framework [9] and the collaborative governance framework [10] and adopts a social network approach to examine power issues and stakeholders' core beliefs as relational concepts [11]. Core beliefs are basic assumptions on causal relations and value systems that orient actors' political actions [12]. On this basis, we address the issues of lacking effectiveness and poor implementation of the provincial forest law by asking the following research questions: (1) What are the existing core beliefs in Salta, and how do their proponents organize into advocacy coalitions? (2) How do core belief groups match with policy network clusters, and how does this affect implementation of forest law?

The protection of tropical forests is a global challenge $[1,13,14]$. The weak enforcement of forest law is one of the key reasons for ongoing deforestation, along with power imbalance among policy actors involved in the governance process $[15,16]$. This study aims to provide insights that might help to strengthen collaborative forest law governance.

\subsection{Research Context}

Salta is one of the country's most extensively forested provinces, and it was among the first to issue its forest law implementation regulations [17]. Since the forest law came into force, more than 30,000 hectares have been deforested in areas that were recategorized as having "low conservation value" [5].

From 2011 onwards, there has been intense scientific debate about the setup of the forest law and the effectiveness of various implementation regulations found in the provinces of the Gran Chaco ecoregion [18-21]. A large coalition of nongovernmental organizations (NGOs) and members of the federal parliament advocating for the preservation of native forests was instrumental both in the law's adoption and in creating a fund to provide payments for ecosystem services [22]. Peaks in deforestation recorded in the Argentinean Chaco around 2005 and 2006 - driven by agribusiness-related soy expansion [13,23,24]—sparked wider public awareness, galvanizing support for drafting of the new law [25].

The presence of power imbalances and contrasting development visions among actors in Salta has been widely documented in the literature [7,17,22,26-28]. The main arguments put forward to explain the ineffectiveness of the law are the low levels of process-related inclusivity and participation, as well as the contrasting visions and unequal influence of different actors in the formulation and implementation of the provincial law $[4,7,26,27,29]$. There is a substantial amount of literature on the dichotomy between conservation- and production-focused views of the forest $[7,8,17,22]$.

\subsection{Conceptual Framework}

The advocacy coalition framework [9] indicates that advocacy coalitions are the result of complex interactions between core beliefs based on beliefs and behavior. These coalitions may be detected in public declarations, open-ended interviews, and interfaces among policy actors captured via policy network interactions [30].

Here, collaborative governance is defined as follows: "A governing arrangement where one or more public agencies directly engage non-state stakeholders in a collective decision-making process that is formal, consensus-oriented, and deliberative and that aims to make or implement public policy or manage public programs or assets" [3:244].

Two insights from previous studies are particularly relevant with regard to our research questions. The first is that advocacy coalitions need to coordinate behavior and beliefs to achieve policy outcomes [9]. The second is that a small number of powerful actors can capture the policy-making process and preclude a collaborative outcome [10]. 
It is widely recognized in network theory that connections between nodes mostly occur among nodes with homogenous characteristics. This property is called homophily [31]. It constitutes a limitation for actors who belong to such systems, and presents an obstacle to shared understanding. The higher the level of homophily in a network, the more important it becomes to identify actors who are heterophilous and play a bridging role across groups [32]. Actors that act as brokers are typically relatively powerful, and one of their key properties is that of "multivocality", i.e., the capacity to be perceived as allies by different actors with different beliefs [33].

Social network analysis takes actors' interdependence as a point of departure [31]. Methodologically, the study of policy networks is the study of a bounded, defined set of actors and the relations between them [34]. The study of networked governance is the study of those relations among key stakeholders that impact governance outcomes (ibid). Simultaneous mapping of multiple ties that captures different dimensions of collaboration enables a "thicker" description of the policy space [31].

\section{Data and Methods}

This study focuses on the policy forums set up for implementation or discussion of the forest law in Salta. The forums were useful in defining the list of policy actors to interview and the boundaries of forest governance implementation in Salta. We adopted a multilevel governance framework to analyze connections between policy actors belonging to different forums at the local, provincial, and national levels. Our aim was twofold. First, we aimed to identify the beliefs of forest governance actors that we refer to as core beliefs. Second, we aimed to analyze their interactions in the policy networks associated with the relevant policy forums for implementation of the forest law. We adopted a mixed-method and sequential research design, integrating social network analysis with content analysis and combining quantitative and qualitative analysis techniques.

Data were obtained from fieldwork and a survey conducted between May 2018 and February 2019 on Salta's forest governance policy. To validate the consistency of the choice of policy forums, the first author participated in various meetings and conducted interviews with expert informants (mainly forum coordinators or forum participants).

Following this validation phase, we conducted face-to-face or telephone interviews with representatives in a leadership position of all organizations participating in the five selected forums (see Supplementary Material 1 for a description of the forums). The forums include different types of policy actors from the private sector, state agencies, academia, NGOs, and forest inhabitants' local organizations. Our sample of governance policy actors comprises 59 organizations (Supplementary Material 2). The overall response rate was $86.4 \%(52 / 59)$.

We adapted an established survey instrument [35] that was originally developed within the international research project Comparing Climate Change Policy Networks (COMPON). The instrument is presented in Supplementary Material 3 and the organizations' participation in policy forum in Supplementary Material 4. We collected four types of data: network data, node attributes, multiple-choice opinion statements, and textual data.

We focused on three networks that are considered in the literature to be the most relevant ones describing the dimensions of policy collaboration [35]. We asked all participating actors to report their relationships with all the other 58 actors concerning: (1) long-term mutual policy support; (2) exchange of scientific or technical information; and (3) meetings. We argue that power and core beliefs are reflected in the deliberate ties between actors.

Attribute data on actors - the nodes in our network study-included type of organization, organizational scale, main source of funding (provincial, federal, national, international), and the prominence of forest policy in their activities; respondents' perceptions of other policy actors' influence on forest governance; as well as multiple-choice opinion statements describing socio-ecological risks and policy, and respondents' evaluation of tenure regularization and forest policy instruments in Argentina. Textual data derive from the open-ended section of the interview. This was designed to collect policy actors' dis- 
courses on socio-ecological risks, land tenure regularization, and forest management policy. Comparison of these textual data with the multiple-choice opinion statements enabled us to better understand policy actors' beliefs.

Overall, the combination of different types of data and methods was intended to provide a comprehensive understanding of forest policy governance characterized by a high level of disjunction between different interests driving policy actors' actions.

\subsection{Core Beliefs}

\subsubsection{Identification of Core Beliefs}

We developed our set of core beliefs by analyzing literature on contrasting visions of native forests in Argentina and the main motivations driving their use [22,26,28,36-38] as well as political-economy views of global environmental politics [39]. Observation of policy actors by the authors during fieldwork complemented the literature review.

\subsubsection{Assignment of Actors to Core Beliefs}

We took two approaches to identifying clusters deriving from beliefs: the first was based on the analysis of opinion statements, the second was based on experts' assignment of actors to core beliefs.

For the first approach, we developed opinion statements to capture the visions of forest policy actors with respect to forest management, forest tenure systems, and climate change (Supplementary Material 3). We focused on these three topics, as they proved key to the forest governance system and enabled us to identify actors' core beliefs. Their selection was based on the survey instrument we adapted [35], as well as on a series of discussions with local key stakeholders.

We built a bimodal matrix (actor $x$ belief) in which each opinion statement was measured on a 1-to-5 Likert scale from "agree" to "disagree" [40]. We then applied the "tabu" search routine to identify relevant coalitions. All the network measures and graphs were produced using the UCINET software [41]. This is a menu-driven software for Windows [42].

For the second approach, four independent experts were tasked with classifying the actors according to different core beliefs. The experts were researchers and policy-makers that are prominent in this field but had no previous direct connection to our research. This guaranteed that their knowledge on forest governance was independent from that of the authors. To assess the reliability of the agreement between experts, we calculated the Fleiss Kappa coefficient. This index is used to measure the nominal rate of agreement between multiple coders [43]. This step, hereafter referred to as "expert classification", served to further validate the strength of our initial identification of core beliefs. In addition, we compared and validated the results of the expert assessment with those of our content analysis of open-ended interviews with policy actors. These qualitative interview sections served to illustrate stakeholders' perceptions of problems, their proposed solutions, and their forest-related core beliefs.

\subsection{Identification of Network Clusters}

Our analysis concentrated on the long-term support network, as it appeared the most meaningful. Among the three networks identified, it displayed the strongest collaborationbased ties [44] between the actors. Further, the high level of correlation between the three networks - evidenced by the Quadratic Assignment Procedure test result of over 0.57 correlation-reinforced our decision to focus exclusively on the long-term support network. We created network clusters using a clustering routine based on the "tabu" search algorithm that groups together actors who share the same patterns of interaction [45].

\subsection{Comparison of Core Belief Groups with Network Clusters}

Next, we compared the clusters resulting from the experts' classification with the clusters derived from reported behavior (policy networks). We used network data to check 
the level of matching between beliefs (core beliefs) and behavior (networks) at both group and actor levels. We re-clustered the networks into groups using an algorithm called "faction partitioning" [45] in UCINET [41]. We then visualized the network graph using the multidimensional-scaling algorithm in UCINET that depicts nodes closer to each other on the graph when they have a similar network pattern [46].

Network structures can be difficult to divide into clusters, as they often present a coreperiphery pattern [47]. To better interpret the mismatch at the group level, we analyzed three elements at the actor level: homophily, reputational influence, and network centrality.

Homophily was measured by means of the E-I index. The E-I index is a measure of in-group versus out-group preference. It subtracts the number of out-group ties from the number of in-group ties, and divides the result by the total number of ties [48]. An E-I score of -1 means complete homophily, i.e., the node has relationships only with in-group actors. A score of 1 means complete heterophily, i.e., the node is connected only with out-group actors.

Reputational influence [49] is viewed as a proxy for the power of individual policy actors [50]. We calculated a reputational influence measure based on survey results. It represented the modal category (most frequent value) of the influence score assigned.

Network centrality describes the actor's position in the network. The most central actors are the ones with the highest numbers of connections [31]. This measure can be considered a proxy of power in policy networks [50].

\section{Results}

This section presents the core beliefs identified, the experts' classification of the actors, the network clusters, the comparison between the belief groups resulting from the expert classification and the clusters derived from the network analysis, and some key characteristics at the actor level.

\subsection{Core Beliefs}

We identified three core beliefs centering on "profit maximization", "livelihoods", and "conservation", respectively. The actors were categorized into three groups according to these core beliefs.

Actors in the profit maximization category exhibited forest use preferences geared towards maximizing economic returns per hectare. These actors viewed environmental restrictions on land use as an obstacle to profit maximization. They demanded compensation for profit losses deriving from environmental regulations on production.

Actors in the second category perceived the forest as a crucial source of livelihood among criollos (small-scale cattle ranchers) and indigenous people. These actors felt that land use should primarily support the rights of people living in the forest, enabling smallscale criollo peasants and indigenous peoples to maintain their livelihood systems, which the actors perceived to be under threat from agricultural expansion. The criollos make a living from extensive subsistence cattle ranching, while local indigenous peoples depend on the remaining native forests for cultural, economic, and social purposes.

Actors assigned to the conservation category emphasized the importance of forest ecosystem services and biodiversity. They prioritized the conservation of natural resources and the promotion of productive activities that are compatible with such protection.

\subsection{Assignment of Actors to Core Beliefs}

\subsubsection{Analysis of Opinion Statements}

The analysis of opinion statements cannot provide a complete classification of all differences in understanding of forest governance goals among actors. The answers to opinion statements (Supplementary Material 3, Sections 1 and 3) are very similar among respondents: either most of them agree with a given statement, or most of them disagree (Figure 1). 


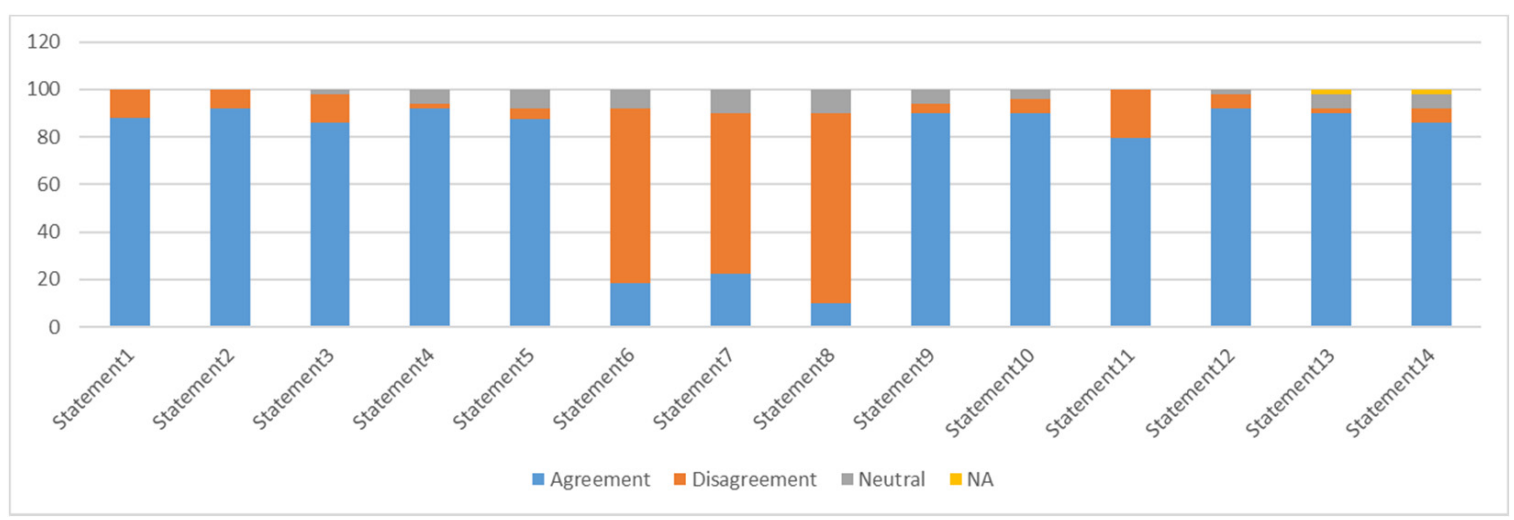

Figure 1. Multiple-choice opinion statements results.

The tabu search cluster analysis revealed three groups: one large group containing over $80 \%$ of the organizations and two very small groups composed of two and four organizations, respectively. This suggests that the majority of actors subscribe to roughly the same policy narrative: namely, they consider adopting sustainable forest management practices and regularizing land tenure to be very important. At the same time, the opinion statements indicate a broad range of definitions of sustainable forest management, leaving ample room for interpretation by individual actors.

\subsubsection{Expert Classification}

The outcome of the experts' assignment of actors to core beliefs is presented in Table 1. Civil-society organizations (CSOs), which include NGOs and local organizations, are mainly found in the livelihoods group. Governmental bodies, which include both federal and provincial agencies, are evenly represented in the three core belief groups. Agribusiness organizations, representing large producers, focus mainly on profit maximization; however, it is worth noting that two of them have a strong interest in conservation. Research organizations, which include universities (as a whole) and other research organizations, were classified into the profit maximization and the conservation groups.

Table 1. Experts' classification of forest governance actors into core beliefs.

\begin{tabular}{cccccc}
\hline & Governmental & CSOs & Agribusiness & Research & Total \\
\hline $\begin{array}{c}\text { Profit } \\
\text { maximization }\end{array}$ & 8 & 0 & 10 & 1 & 19 \\
\hline Livelihoods & 10 & 14 & 0 & 0 & 24 \\
\hline Conservation & 8 & 4 & 2 & 2 & 16 \\
\hline Total & 26 & 18 & 12 & 3 & 59 \\
\hline
\end{tabular}

The level of agreement among experts was fairly high. As many as 39 actors were assigned to the same group by all four experts, whereas one expert disagreed in 11 cases. In 9 cases, only two experts agreed on the classification. The validity of the experts' classification is also shown by the intercoder reliability test, with a Fleiss' kappa coefficient of 0.7 (Table 2).

Table 2. Intercoder reliability of expert classification.

\begin{tabular}{cc}
\hline $\mathrm{m}$ (number of coders) & 4 \\
\hline $\mathrm{N}$ (number of policy actors to classify) & 59 \\
\hline Fleiss' kappa coefficient & 0.704867 \\
\hline s. e. (standard error) & 0.477781 \\
\hline
\end{tabular}




\subsubsection{Content Analysis}

By performing content analysis on the actors' responses to our open-ended interview questions, we aimed to gain deeper insight into the various core beliefs of the different actor categories. We specifically looked for units of text that fit with our three main definitions of core beliefs: profit maximization, livelihoods, and conservation. The results of the analysis confirm that the narratives differ significantly between the three groups. This can be seen by looking at some representative statements from the different groups.

For example, from the group focused on "profit maximization", the following statement illustrates that the main driver of forest use is its expected economic value: "We do not deforest to deforest; we deforest looking at how much money we will get, or which added value will be produced or which gross margin we will get." "“No se desmonta por desmontar, se desmonta viendo que plata se va a sacar o qué valor agregado se va a sacar o que margen bruto uno va a tener." 23.int.01.10.18, p. 1.).

Conversely, for the group focused on "livelihoods", the following statement illustrates their belief in the right of indigenous peoples and criollos to use the forest according to their own livelihood systems. "It is key that the most powerful sectors, the richest of Argentina, acknowledge that there are indigenous and peasant populations that have a right to the land, with rights to water, to production, and to making a living rather than just being welfare recipients." ("Es clave que los sectores más poderosos, más ricos de la Argentina, reconozcan que hay poblaciones indígenas y campesinas con derechos a la tierra, con derechos al agua, con derechos a la producción y al inferir sus vidas y no ser solamente sujetos asistenciales." 30.int.05.10.18, p. 2.).

For the group focused on conservation, the following statement illustrates their belief in the importance of evaluating forest management practices based on their environmental impact rather than the presence or absence of production activities. "There is a misunderstanding of what sustainable forest management or forest conservation means. It is usually interpreted as absolute protection of the forest, without any type of even low-intensity productive use." ("Hay una mala interpretación de lo que significa manejo sustentable o conservación de bosques, se lo suele interpretar como que es una protección absoluta del bosque sin ningún tipo de aprovechamiento productivo de baja intensidad." 49.int.03.12.18 p.1.).

\subsection{Network Clusters}

The faction partitioning routine produced three clusters, achieving a fit of 0.711 . This statistic indicates that the algorithm-based clustering corresponds fairly well with the observed clustering. Figure 2 shows these clusters in the network. Each actor is represented as a node in the network. Ties between nodes indicate long-term collaboration and policy support for a common goal during policy discussions (see Supplementary Material 3, Sections 2 and 3, Question 3). The different colors represent the three network clusters.

The graph is based on the non-metric multidimensional scaling of a proximity matrix. We made a few minor adjustments to allow for a better visualization of all node labels. The graph shows that the faction partitioning routine does not provide three cohesive groups, as some nodes are located far from their respective network clusters. 


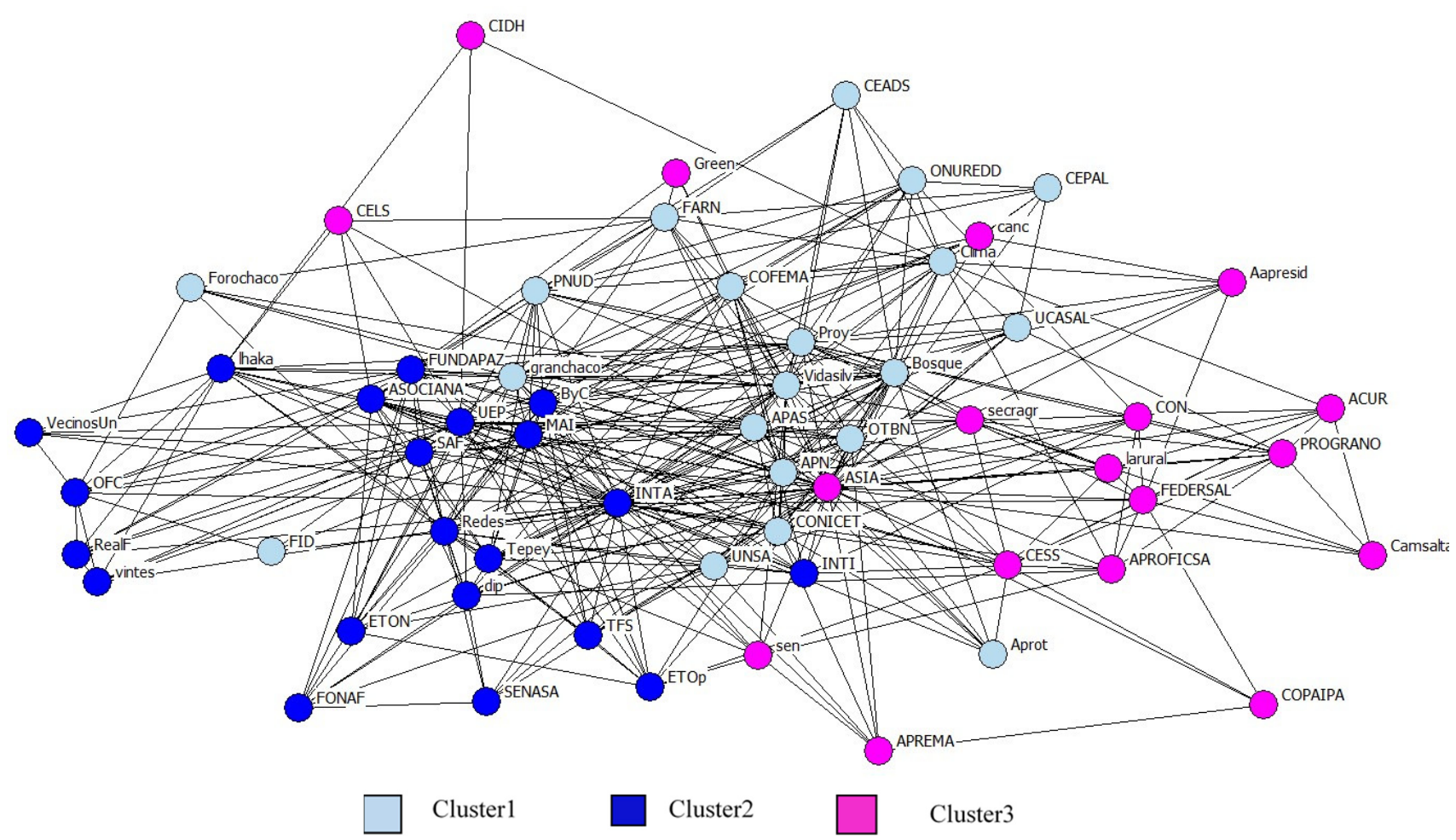

Figure 2. Long-term policy support network. Layout: Non-metric multidimensional scaling geodistance.

\subsection{Congruence and Mismatches between Core Belief Groups and Network Clusters}

We compared the degree to which the network clusters matched the experts' classification. There is a high level of congruence for the livelihoods group and a lower level for the conservation group. In the case of the livelihoods group, $78 \%$ of the actors classified by the experts were in the same network cluster. In the case of the profit maximization group, $63 \%$ were in the same cluster, and for the conservation group, $55 \%$ were in the same cluster.

We then analyzed the links between actors' position on the network and their core beliefs. Figure 3 represents the long-term policy support network, with colors indicating core beliefs and node size indicating actors' level of reputational influence. It shows that ties occur mostly within sub-groups of actors sharing the same core beliefs (same node color). However, notably, most conservation actors also collaborate with and support others that have different core beliefs. The E-I index of conservation actors was 0.1 on average, indicating that they connect with the same number of actors within their own group as actors from other groups. The other two actor categories displayed a prevalence for homophily (E-I index of -0.1). The three network clusters have a low level of density ranging between 0.2 and 0.3 . The graph points to the presence of a core-periphery structure. The core of the network contains nodes of all three colors, i.e., actors of all three core beliefs. In contrast, nodes at the periphery are clustered by color, indicating clusters of actors sharing the same core belief. In social network analysis, this indicates a densely connected core and a much less connected periphery. 


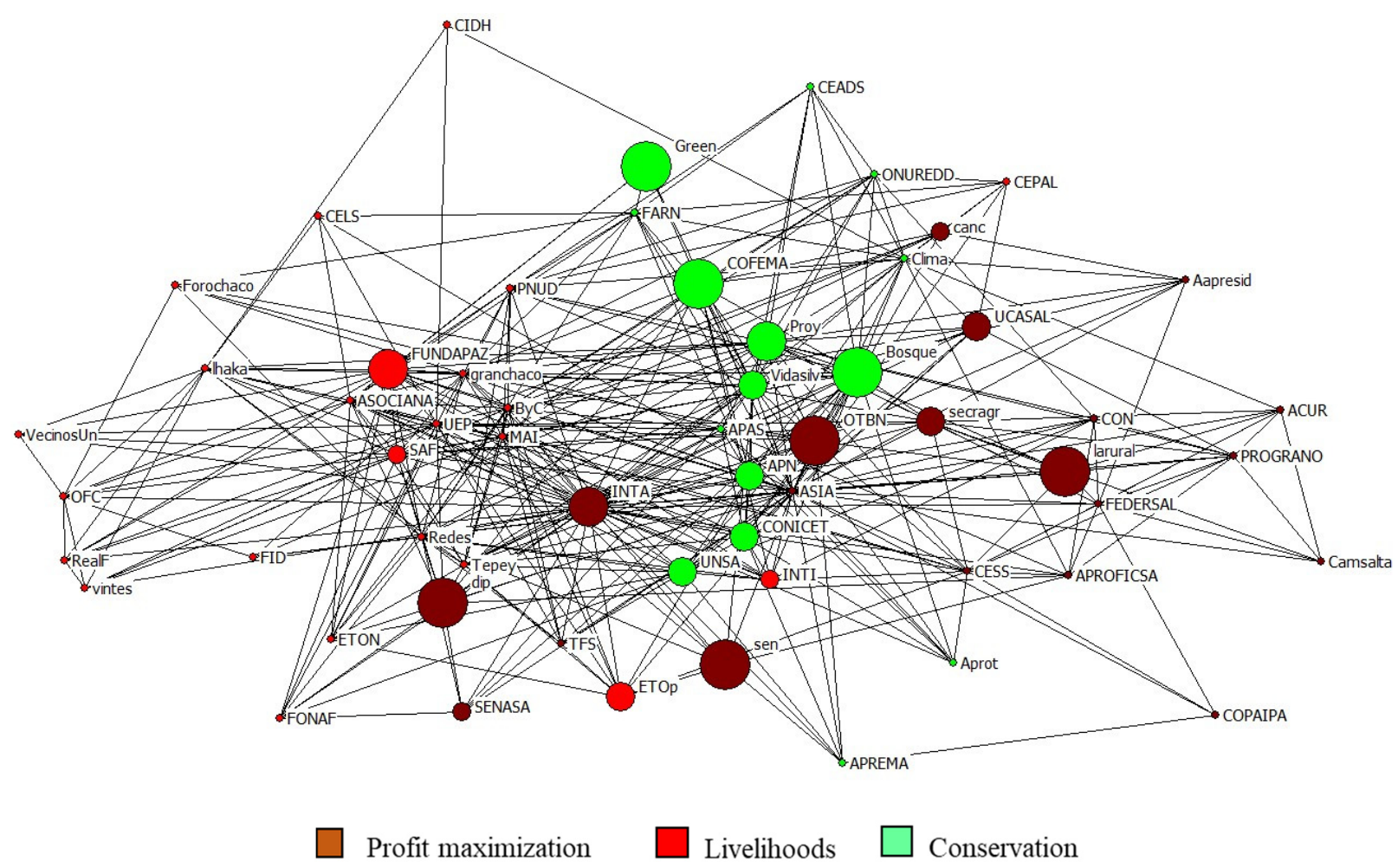

Figure 3. Actors' core beliefs and reputational influence. Layout: Non-metric multidimensional scaling geodistance.

\section{Discussion}

\subsection{Core Beliefs and Advocacy Coalitions}

The main arguments put forward to explain the ineffectiveness of Argentina's forest law in Salta are the low levels of process-related inclusivity and participation, as well as the contrasting visions and unequal influence of different actors in the formulation and implementation of the provincial law $[4,7,26,27,29]$. Our work complements previous literature which argues that enforcement of the law depends on the strength of the proand anti-deforestation coalitions [7]. This study does not take these coalitions for granted but rather provides a fine-grained analysis of their structure and functioning. Our results suggest that the conservation coalition is not missing in Salta as suggested in previous literature [7]; rather, it lacks coordination, as actors supporting this objective are fragmented into different policy networks.

We defined three main core beliefs that describe the motivations of policy actors. The analysis of both the core beliefs and the behavior of actors enabled us to understand sources of weakness of their advocacy coalitions. Are actors' beliefs consistent within each coalition? Our analysis at the group level shows that core beliefs and network clusters are not fully congruent: some actors escape straightforward network or expert classification. We argue that this weakens the coalitions, as coalitions require coordination between behavior and beliefs to achieve strength and policy outcomes [9]. To deepen our insight in this regard, we analyzed reputational influence and network centrality at the actor level.

\subsection{Impact of Weak Advocacy Coalitions and Multivocal Actors on Law Implementation}

According to the power dynamics model [51], policy-makers are restricted in their decision-making by the power of dominant actors in the network and by dominant narratives [52]. This can weaken forest law implementation, for example, when influential actors have the power to steer decision-making towards their objectives at the expense of actors with other core beliefs.

The network graph in Figure 3 (Section 3.4) indicates that the most central actors in the networks are not necessarily the most influential. The 10 most influential forest governance 
actors included five actors focused on profit maximization, four focused on conservation, and one focused on livelihoods. Among these, four actors stand out with regard to two features: they are (1) heterophilous according to the E-I index and (2) their classification by experts based on policy preferences did not match with the network clustering based on the faction partitioning routine.

We suggest classifying these actors as "multivocal" [33]. Their power derives from their position in the network and their ambivalence regarding particular policy narratives. They have a bridge function to other actors with different core beliefs. Overall, they have the ability to be perceived as allies by actors with different core beliefs because they do not openly pursue any specific goal.

Comparative analysis of collaboration networks and core beliefs can improve understanding of policy governance processes in situations characterized by contrasting beliefs, different levels of influence, and a need for actors to use a language that emphasizes similarities rather than differences to stand their ground in the policy arena. The methodological approach adopted in this study in the context of Salta can also be used to help navigate governance of resource and commodity frontiers $[53,54]$ in other countries. For example, a recent study on Indonesia's forest policy used the advocacy coalition framework to understand the conditions that have allowed NGOs to reduce deforestation patterns through a series of coordinated behaviors among stakeholders [55]. Another article combines discourse network analysis with the advocacy coalition framework to understand tree plantation policy in South Africa [56].

\section{Conclusions}

In this article, we examined governance of the forest law implementation process in Salta province, Argentina. The law prescribes that enforcement must occur in a participatory process, through collaborative governance. However, the literature suggests that implementation of the forest law in Salta has not been effective to date [7]. We adopted a networked governance approach to understand actors' core beliefs and the structure and functioning of advocacy coalitions. We systematically analyzed actors' core beliefs, their interactions in policy networks, and how these impact governance outcomes.

We obtained a number of notable results by combining expert classification and analysis of actors' narratives and policy networks. At the group level, core beliefs are fairly consistent with the way in which the network is clustered. However, the presence of some inconsistencies at both group and actor levels reduces the strength of advocacy coalitions. This has weakened the governance process related to the implementation of the forest law. We believe that the policy process could be improved if actors adopted clearer policy positions on specific issues.

We argue that further research should examine the narratives and the strategic behavior of actors concerning a specific controversial topic. The mixed-methods design we used for our study enables nuanced understanding of actors' roles within the policy space. Our key contribution to collaborative governance analysis is our focus on actors in a policy space characterized by a high level of contestation. We studied how they speak and behave, examined their narratives, and investigated their collaboration networks. Our analysis offers insights that can help actors strengthen the implementation of Salta's forest law. Our methodological approach holds promise for the analysis of other governance systems where multiple stakeholders engage in consensus-oriented decision-making.

Supplementary Materials: The following are available online at https:/ / www.mdpi.com/article / $10.3390 /$ su131810000/s1. Material 1 List of policy forums for sample definition Material 2 List of organizations interviewed present in the sample with acronym Material 3 Data collection instrument used for the policy network survey (in Spanish) Material 4 Participation in policy forums of the actors interviewed. 
Author Contributions: C.I.: Conceptualization, Methodology; Formal Analysis, Investigation, Writing-Review \& Editing. M.G.C.: Writing-Review \& Editing, Supervision; Project Administration; Funding Acquisition. M.T.: Writing-Review \& Editing. D.C.: Methodology; Formal Analysis, Investigation, Writing-Review \& Editing; Supervision. All authors have read and agreed to the published version of the manuscript.

Funding: This research was funded by the European Research Council (ERC), grant number INCLUDE 681518.

Institutional Review Board Statement: The study was conducted according to the guidelines of the Declaration of Helsinki, and approved by the Director of Centre for Development and Environment of the University of Bern, (date approval: 20 March 2018) and by Ethics Committee of Facultad de Filosofía y Letras of University of Buenos Aires (UBA), (date of approval: 9 March 2018).

Informed Consent Statement: Informed consent was obtained from all subjects involved in the study.

Acknowledgments: The authors would like to thank Anu Lannen and Marlène Thibault for editing the manuscript.

Conflicts of Interest: The authors declare that they have no known competing financial interests or personal relationships that could have appeared to influence the work reported in this article.

\section{References}

1. Kuemmerle, T.; Altrichter, M.; Baldi, G.; Cabido, M.; Camino, M.; Cuellar, E.; Cuellar, R.L.; Decarre, J.; Díaz, S.; Gasparri, I.; et al. Forest conservation: Remember Gran Chaco. Science 2017, 355, 465. [CrossRef]

2. Patrouilleau, M.; Mioni, W. Políticas Públicas en la Ruralidad Argentina; Ediciones INTA; Instituto de Prospectiva y Políticas Públicas, Centro de Investigación en Ciencias Políticas, Económicas y Sociales_INTA: Ciudad Autónoma de Buenos Aires, Spain, 2017.

3. Sarmiento Barletti, J.P.; Larson, A.M. The Role of Multi-Stakeholder Forums in Subnational Jurisdictions: Framing Literature Review for in-Depth Field Research; Occasional Paper 194; Center for International Forestry Research: Bogor, Indonesia, 2019. [CrossRef]

4. Aguiar, S.; Mastrangelo, M.E.; Collazo, M.A.G.; Sans, G.H.C.; Mosso, C.E.; Ciuffoli, L.; Schmidt, M.; Vallejos, M.; Langbehn, L.; Brassiolo, M.; et al. ¿Cuál es la situación de la Ley de Bosques en la Región Chaqueña a diez años de su san-ción? Revisar su pasado para discutir su futuro. Ecol. Austral. 2018, 28, 400-417. [CrossRef]

5. Barboza, A.G.J.S.; Pocoví, J.M.C.; Venencia, C.; Huaranca, L.L.; Agüero, J.L.; Iribarnegaray, M.A.; Escosteguy, M.; Volante, J.N.; Seghezzo, L. Ten years of contested enforcement of the Forest Law in Salta, Argentina. The role of land-change science and political ecology. J. Land Use Sci. 2019, 15, 221-234. [CrossRef]

6. Volante, J.N.; Mosciaro, M.J.; Gavier-Pizarro, G.I.; Paruelo, J.M. Agricultural expansion in the Semiarid Chaco: Poorly selective contagious advance. Land Use Policy 2016, 55, 154-165. [CrossRef]

7. Milmanda, B.F.; Garay, C. Subnational variation in forest protection in the Argentine Chaco. World Dev. 2019, 118, 79-90. [CrossRef]

8. Milmanda, B.F.; Garay, C. The Multilevel Politics of Enforcement: Environmental Institutions in Argentina. Politi. Soc. 2019, 48, 3-26. [CrossRef]

9. Weible, C.M.; Ingold, K.; Nohrstedt, D.; Henry, A.D.; Jenkins-Smith, H. Sharpening advocacy coalitions. Policy Stud. J. 2019, 48, 1054-1081. [CrossRef]

10. Ansell, C.; Gash, A. Collaborative Governance in Theory and Practice. J. Public Adm. Res. Theory 2007, 18, 543-571. [CrossRef]

11. Knoke, D. Networks of Political Action: Toward Theory Construction. Soc. Forces 1990, 68, 1041-1063. [CrossRef]

12. Sabatier, P.A. An advocacy coalition framework of policy change and the role of policy-oriented learning therein. Policy Sci. 1988, 21, 129-168. [CrossRef]

13. Lambin, E.F.; Meyfroidt, P. Global land use change, economic globalization, and the looming land scarcity. Proc. Natl. Acad. Sci. USA 2011, 108, 3465-3472. [CrossRef] [PubMed]

14. Tanentzap, A.J.; Lamb, A.J.; Walker, S.P.; Farmer, A. Resolving conflicts between agriculture and the natural environment. PLoS Biol. 2015, 13, e1002242. [CrossRef]

15. Pacheco, P.; Mo, K.; Dudley, N.; Shapiro, A.; Aguilar-Amuchastegui, N.; Ling, P.Y.; Anderson, C.; Marx, A. (Eds.) World Wildlife Fund. In Deforestation Fronts Drivers and Responses in a Changing World; WWF: Gland, Switzerland, 2021.

16. Jacobi, J.; Llanque, A. "When we stand up, they have to negotiate with us": Power relations in and between an agroindustrial and an indigenous food system in Bolivia. Sustainability 2018, 10, 4001. [CrossRef]

17. Schmidt, M.A. 'Ordenadores y ordenados'. Actores en disputa en el ordenamiento territorial de bosques nativos en la provincia de Salta. Cuad. De Antropol. 2014, 11, 37-55.

18. Alcañiz, I.; Gutierrez, R.A. Between the Global Commodity Boom and Subnational State Capacities: Payment for Environmental Services to Fight Deforestation in Argentina. Glob. Environ. Politi. 2020, 20, 38-59. [CrossRef]

19. Ceddia, M.G.; Zepharovich, E. Jevons paradox and the loss of natural habitat in the Argentinean Chaco: The impact of the indigenous communities' land titling and the Forest Law in the province of Salta. Land Use Policy 2017, 69, 608-617. [CrossRef] 
20. Nolte, C.; Gobbi, B.; Waroux, Y.L.P.D.; Piquer-Rodríguez, M.; Butsic, V.; Lambin, E.F. Challenges in attributing avoided deforestation to policies and actors: Lessons from provincial forest zoning in the Argentine dry chaco. Ecol. Econ. 2018, 150, 346-352. [CrossRef]

21. Volante, J.N.; Seghezzo, L. Can't See the Forest for the Trees: Can Declining Deforestation Trends in the Argentinian Chaco Region be Ascribed to Efficient Law Enforcement? Ecol. Econ. 2018, 146, 408-413. [CrossRef]

22. Astelarra, S.; Beltramino, T.; Fernández, L.; Bouzo, S.F.; Langbehn, L.; Larsimont, R.; Martín, F.; Montera, C.; Ramírez, D.; Scharager, A.; et al. Arenas públicas, modelos de desarrollo y políticas de protección del ambiente: La Ley de Bosques entre 'conservación' y ‘producción. In Cartografías del Conflicto Ambiental en Argentina II; Ediciones CICCUS CLACSO; Merlinski, G., Ed.; Fundación CICCUS: Ciudad Autónoma de Buenos Aires, Spain, 2019. [CrossRef]

23. Boletta, P.E.; Ravelo, A.C.; Planchuelo, A.M.; Grilli, M. Assessing deforestation in the Argentine Chaco. For. Ecol. Manag. 2006, 228, 108-114. [CrossRef]

24. Grau, H.R.; Gasparri, N.I.; Aide, T.M. Balancing food production and nature conservation in the Neotropical dry forests of northern Argentina. Glob. Chang. Biol. 2008, 14, 985-997. [CrossRef]

25. Hufty, M. Pizarro protected area: A political ecology perspective on land use, soybeans and Argentina's nature conservation policy. In People, Protected Areas and Global Change: Participatory Conservation in Latin America, Africa, Asia and Europe; Perspectives of the Swiss National Centre of Competence in Research (NCCR) North-South, University of Bern; Galvin, M., Haller, T., Eds.; Geographica Bernensia: Bern, Switzerland, 2008; Volume 3, pp. 145-173.

26. Huaranca, L.L.; Iribarnegaray, M.A.; Albesa, F.; Volante, J.N.; Brannstrom, C.; Seghezzo, L. Social perspectives on deforestation, land use change, and economic development in an expanding agricultural frontier in Northern Argentina. Ecol. Econ. 2019, 165, 106424. [CrossRef]

27. Mastrangelo, M.E.; Aguiar, S. Are Ecological Modernization Narratives Useful for Understanding and Steering Social-Ecological Change in the Argentine Chaco? Sustainability 2019, 11, 3593. [CrossRef]

28. Seghezzo, L.; Volante, J.N.; Paruelo, J.M.; Somma, D.J.; Buliubasich, E.C.; Rodríguez, H.E.; Gagnon, S.; Hufty, M. Native forests and agriculture in Salta (Argentina): Conflicting visions of development. J. Environ. Dev. 2011, 20, 251-277. [CrossRef]

29. Schmidt, M. (Des)ordenamientos Territoriales Salteños. Una Aproximación al Contexto Previo al Ordenamiento Territorial de Bosques Nativos en la Provincia de Salta. Mundo Agrario 2014, 15, 1-26.

30. Ocelík, P.; Svobodová, K.; Hendrychová, M.; Lehotský, L.; Everingham, J.-A.; Ali, S.; Badera, J.; Lechner, A. A contested transition toward a coal-free future: Advocacy coalitions and coal policy in the Czech Republic. Energy Res. Soc. Sci. 2019, $58,101283$. [CrossRef]

31. Robins, G. Doing Social Network Research: Network-based Research Design for Social Scientists; SAGE Publications Ltd.: Thousand Oaks, CA, USA, 2015. [CrossRef]

32. Di Gregorio, M.; Fatorelli, L.; Paavola, J.; Locatelli, B.; Pramova, E.; Nurrochmat, D.R.; May, P.H.; Brockhaus, M.; Sari, I.M.; Kusumadewi, S.D. Multi-level governance and power in climate change policy networks. Glob. Environ. Chang. 2018, 54, 64-77. [CrossRef]

33. Padgett, J.F.; Ansell, C.K. Robust action and the rise of the Medici, 1400-1434. Am. J. Sociol. 1993, 98, 1259-1319. [CrossRef]

34. Christopoulos, D. Governance networks in politics. In Networked Governance; Hollstein, B., Matiaske, W., Schnapp, K.U., Eds.; Springer International Publishing: Cham, Switzerland, 2017; pp. 55-70. [CrossRef]

35. Gronow, A.; Ylä-Anttila, T. Cooptation of ENGOs or Treadmill of Production? Advocacy Coalitions and Climate Change Policy in Finland. Policy Stud. J. 2016, 47, 860-881. [CrossRef]

36. Naharro, N.; Alvarez, M.A.; Flores Klarik, M. Territorios en disputa: Reflexiones acerca de los discursos que legitiman la propriedad de la tierra en el Chaco salteño. In El Desarrollo y Sus Lógicas en Disputa en Territorios del Norte Argentino; Manzanal, M., Villarreal, F., Eds.; Ediciones Ciccus: Buenos Aires, Spain, 2010. [CrossRef]

37. Baumann, M.; Piquer-Rodríguez, M.; Fehlenberg, V.; Pizarro, G.G.; Kuemmerle, T. Land-use competition in the South American Chaco. In Land Use Competition; Niewöhner, J., Bruns, A., Hostert, P., Krueger, T., Nielsen, J.Ø., Haberl, H., Lauk, C., Lutz, J., Müller, D., Eds.; Springer International Publishing: Cham, Switzerland, 2016; pp. 215-229. [CrossRef]

38. Zepharovich, E.; Ceddia, M.G.; Rist, S. Perceptions of deforestation in the Argentinean Chaco: Combining Q-method and environmental justice. Ecol. Econ. 2020, 171, 106598. [CrossRef]

39. Clapp, J.; Dauvergne, P. Paths to a Green World: The Political Economy of the Global Environment; The MIT Press: Cambridge, MA, USA, 2011. [CrossRef]

40. Metz, F.; Ingold, K. Politics of the precautionary principle: Assessing actors' preferences in water protection policy. Policy Sci. 2017, 50, 721-743. [CrossRef]

41. Borgatti, S.P.; Everett, M.G.; Freeman, L.C. Ucinet 6 for Windows: Software for Social Network Analysis; Analytic Technologies: Cambridge, MA, USA, 2002.

42. Frey, B.B. The SAGE Encyclopedia of Educational Research, Measurement, and Evaluation; SAGE Publications, Inc.: Thousand Oaks, CA, USA, 2018. [CrossRef]

43. Fleiss, J.L. Measuring nominal scale agreement among many raters. Psychol. Bull. 1971, 76, 378-382. [CrossRef]

44. Granovetter, M.S. The strength of weak ties. Am. J. Sociol. 1973, 78, 1360-1380. [CrossRef]

45. De Amorim, S.G.; Barthélemy, J.-P.; Ribeiro, C.C. Clustering and clique partitioning: Simulated annealing and tabu search approaches. J. Classif. 1992, 9, 17-41. [CrossRef] 
46. Borgatti, S.; Everett, M.; Johnson, C. Visualization. In Analyzing Social Networks; Sage Publications, Inc.: Thousand Oaks, CA, USA, 2013.

47. Borgatti, S.; Everett, M.G. Models of core/periphery structures. Soc. Netw. 2000, 21, 375-395. [CrossRef]

48. Everett, M.; Borgatti, S. Categorical attribute based centrality: E-I and G-F centrality. Soc. Netw. 2012, 34, 562-569. [CrossRef]

49. James, S.; Christopoulos, D. Reputational leadership and preference similarity: Explaining organisational collaboration in bank policy networks. Eur. J. Politi. Res. 2017, 57, 518-538. [CrossRef]

50. Ingold, K.; Leifeld, P. Structural and Institutional Determinants of Influence Reputation: A Comparison of Collaborative and Adversarial Policy Networks in Decision Making and Implementation. J. Public Adm. Res. Theory 2014. [CrossRef]

51. Keeley, J.; Scoones, I. Understanding Environmental Policy Processes: Cases from Africa; Routledge: London, UK, 2003.

52. Cáceres, D.M.; Silvetti, F.; Díaz, S. The rocky path from policy-relevant science to policy implementation-A case study from the South American Chaco. Curr. Opin. Environ. Sustain. 2016, 19, 57-66. [CrossRef]

53. Kröger, M.; Nygren, A. Shifting frontier dynamics in Latin America. J. Agrar. Chang. 2020, 20, 364-386. [CrossRef]

54. Durand, L.; Nygren, A.; de la Vega-Leinert, A.C. Naturaleza y Neoliberalismo en América Latina; versión digital CRIM-UNAM (1a edición, 2019); Centro Regional de Investigaciones Multidisciplinarias, Universidad Nacional Autónoma de México: Cuernavaca, México, 2019. [CrossRef]

55. Ruysschaert, D.; Hufty, M. Building an effective coalition to improve forest policy: Lessons from the coastal Tripa peat swamp rainforest, Sumatra, Indonesia. Land Use Policy 2018, 99, 103359. [CrossRef]

56. Malkamäki, A.; Ylä-Anttila, T.; Brockhaus, M.; Toppinen, A.; Wagner, P.M. Unity in diversity? When advocacy coalitions and policy beliefs grow trees in South Africa. Land Use Policy 2021, 102, 105283. [CrossRef] 